\title{
Article \\ Earthworm Abundance Changes Depending on Soil Management Practices in Slovenian Vineyards
}

\author{
Stanko Vršič ${ }^{1, *(D)}$, Marko Breznik ${ }^{1}$, Borut Pulko ${ }^{1}$ and Jesús Rodrigo-Comino ${ }^{2,3}$ (D) \\ 1 University Centre of Viticulture and Enology Meranovo, Faculty of Agriculture and Life Sciences, \\ University of Maribor, Pivola 10, 2311 Hoče, Slovenia; marko.breznik5@gmail.com (M.B.); \\ borut.pulko@um.si (B.P.) \\ 2 Departamento de Análisis Geográfico Regional y Geografía Física, Facultad de Filosofía y Letras, \\ Campus Universitario de Cartuja, University of Granada, 18071 Granada, Spain; jesusrc@ugr.es \\ 3 Department of Physical Geography, University of Trier, 54296 Trier, Germany \\ * Correspondence: stanko.vrsic@um.si
}

Citation: Vršič, S.; Breznik, M.; Pulko, B.; Rodrigo-Comino, J. Earthworm Abundance Changes Depending on Soil Management Practices in Slovenian Vineyards. Agronomy 2021, 11, 1241. https:// doi.org/10.3390/agronomy11061241

Academic Editor: Bhupinder Pal Singh

Received: 25 May 2021

Accepted: 17 June 2021

Published: 19 June 2021

Publisher's Note: MDPI stays neutral with regard to jurisdictional claims in published maps and institutional affiliations.

Copyright: (c) 2021 by the authors. Licensee MDPI, Basel, Switzerland. This article is an open access article distributed under the terms and conditions of the Creative Commons Attribution (CC BY) license (https:/ / creativecommons.org/licenses/by/ $4.0 /)$.

\begin{abstract}
Earthworms are key indicators of soil quality and health in vineyards, but research that considers different soil management systems, especially in Slovenian viticultural areas is scarce. In this investigation, the impact of different soil management practices such as permanent green cover, the use of herbicides in row and inter-row areas, use of straw mulch, and shallow soil tillage compared to meadow control for earthworm abundance, were assessed. The biomass and abundance of earthworms $\left(\mathrm{m}^{2}\right)$ and distribution in various soil layers were quantified for three years. Monitoring and a survey covering 22 May 2014 to 5 October 2016 in seven different sampling dates, along with a soil profile at the depth from 0 to $60 \mathrm{~cm}$, were carried out. Our results showed that the lowest mean abundance and biomass of earthworms in all sampling periods were registered along the herbicide strip (within the rows). The highest abundance was found in the straw mulch and permanent green cover treatments (higher than in the control). On the plots where the herbicide was applied to the complete inter-row area, the abundance of the earthworm community decreased from the beginning to the end of the monitoring period. In contrast, shallow tillage showed a similar trend of declining earthworm abundance, which could indicate a deterioration of soil biodiversity conditions. We concluded that different soil management practices greatly affect the soil's environmental conditions (temperature and humidity), especially in the upper soil layer (up to $15 \mathrm{~cm}$ deep), which affects the abundance of the earthworm community. Our results demonstrated that these practices need to be adapted to the climate and weather conditions, and also to human impacts.
\end{abstract}

Keywords: soil management practices; vineyards; earthworms; human impacts; soil depths

\section{Introduction}

In sloping vineyards, sustainable inter-row soil management practice is key to improve water retention capacity and control of sediment mobilisation [1,2]. The negative consequences of an inadequate soil supply, according to the climatic conditions, are reflected in increased soil erosion rates [3,4], a loss of water and nutrients, greenhouse gas emissions [5] and depletion of soil quality with regard to acidification, salinization, pollution [6] and poor soil structure [7]. The impact of soil management practices on soil biodiversity is focused on specific key indicators such as insects or micro-organisms [8,9]. For example, the presence of earthworms is a clear indicator of the soil's biodiversity status and affects soil quality and productivity [10].

It is well known that earthworms respond differently to diverse soil management practices because they are among the largest soil organisms that are sensitive to the mechanical impacts of tillage [11,12]. When they are widely distributed on a plantation, they are useful bioindicators for sustainable land use [13-15]. The population size in the soil can be assessed to understand the positive or negative impacts of different soil management 
practices (inter and within-row) on the physical and biological properties of soil in vineyards [16]. Earthworms in the soil also have a positively recognised impact on increasing nutrient and water availability, increasing macroaggregate stabilisation [17-19], organic matter degradation and water infiltration through biopores [20]. All of these advantages directly affect soil erosion rates [21] and stimulate microorganisms that form important microbiological products for plants [22]. Earthworm activity is mainly related to soil moisture, the content of organic matter and calcium in the soil [23,24]. Moreover, the addition of organic matter in the vineyard can increase the abundance of endogenous earthworms [25]

It is worth highlighting the elevated number of different environmental conditions and diverse soil management practices carried out in vineyards, i.e., permanent or occasional green covering of soil, mulching (covering with various organic substances), tillage, weed control with herbicides, especially within the row (vine-strip), and combinations of these. Moreover, soil greening in perennial plantations can improve earthworm species diversity and abundance, because plant residues of turfgrass (including roots) are important sources of food for earthworms [24] and show the least negative impact on the earthworm population [16]. In addition, straw mulch generates ideal conditions for self-regulation of soil temperature and humidity, which directly affects earthworms [26,27]. However, herbicides (especially within the row) are used in perennial plantations to control weeds. Their negative effects are reflected in the formation of a less favourable habitat for earthworms as a result of the absence of vegetation cover [28].

The testing of individual soil management practices and their impact on earthworms are common. Faber [11] tested different tillage tools and found no differences in the earthworm population. The lowest impact of tillage was registered when it was tilled in spring during the dry period. In addition to soil tillage, other practices, such as the use of copper [28], can reduce the earthworm population in orchards, which can further reduce soil quality. From an environmental point of view, green cover is more suitable in vineyards than the use of pesticides [16], but only in regions with enough precipitation to avoid exigent water competition and stresses. This needs to be considered seriously. In our research, different soil management practices in the same pedoclimatic conditions were considered, primarily to obtain more objective estimates of the differences between them. These included the most commonly treated soil tillage, short-term use of herbicides (three seasons), permanent green cover, the long-term use of herbicides (over 20 years) and covering the soil with straw (at the start of the experiment).

In Slovenia, more than two-thirds of vineyards are on hill slopes from 10 to $50 \%$, and less than one third are planted on terraces. Permanent green cover is used in most vineyards to reduce soil erosion, and in the part of the country characterised by a continental climate, it represents more than $95 \%$ of soil management in vineyards. In the Mediterranean part, about $45 \%$ of the vineyards are located in the Karst area, and up to $86 \%$ are along the border with the Italian Collio (Ministry of Agriculture, Forestry and Food, Slovenia). Climate change could be affecting this wine-growing area, and the competition for water between vines and green cover plants [3]. Therefore, it is necessary to adopt a correct soil management system to ensure vine productivity and wine quality with the least environmental impact.

Therefore, the main goal of our research was to demonstrate how different soil management practices in steep-slope vineyards impacts earthworm biomass, abundance, their distribution according to soil layers, while considering soil water content and soil temperature. We hypothesize that treatments where the soil is less exposed to solar radiation (i.e., green cover and mulch) would have a more positive impact on earthworm development. Detailed knowledge of this impact would help in the adoption of sustainable soil management practices in vineyards to be adapted, as much as possible, to the climatic and soil conditions of each wine-growing area and biodiversity conditions. 


\section{Material and Methods}

\subsection{Study Site}

This research was conducted in the University Centre (UC) of Viticulture and Enology Meranovo, and the Faculty of Agriculture and Life Sciences, University Maribor, Slovenia, in an experimental active vineyard (Cerkvenjak, $46^{\circ} 57^{\prime} 82.8^{\prime \prime} \mathrm{N} ; 15^{\circ} 94^{\prime} 99.0^{\prime \prime} \mathrm{E}, 245 \mathrm{~m}$ a.s.l.). The study area is a steep-slope vineyard with a $17 \%$ inclination and an exposure to the SE, and was established in 1996 with different white grape varieties according to the traditional Slovenian cultivation system (inter-row: $2.5 \mathrm{~m}$; per vine plant: $1 \mathrm{~m}$ ). The vineyard was cultivated according to the viticultural practice of integrated production with an inter-row permanent green soil cover and the use of herbicides within the row (vine-strip). The study was conducted from April 2014 to October 2016. The average amount of precipitation (1 April to 31 October) was $841 \mathrm{~mm}$ in 2014, $723 \mathrm{~mm}$ in 2015, and $563 \mathrm{~mm}$ in 2016 (the long-term average from $1980-2019$ was $712 \mathrm{~mm}$ ). The average temperatures were $15.9{ }^{\circ} \mathrm{C}$ (2014), $16.6{ }^{\circ} \mathrm{C}(2015)$ and $16.3^{\circ} \mathrm{C}$ (2016), and the values of the Huglin index in these years were 1736,2057 , and $2017^{\circ} \mathrm{C}$ units, which are near the average for the last 10 years $\left(16.45^{\circ} \mathrm{C}\right.$ and $19.81^{\circ} \mathrm{C}$ units, respectively), except in 2014 (Meteorological station Maribor, Slovenian Environmental Agency).

The soils are medium deep loams with a $\mathrm{pH}$ of about $5.4(0.1 \mathrm{~mol} / \mathrm{L} \mathrm{KCl})$. Based on the ammonium lactate extraction procedure, an average sample of soils contains $2.4 \mathrm{mg}$ soluble- $\mathrm{P}_{2} \mathrm{O}_{5}-\mathrm{P}, 21.7 \mathrm{mg}$ soluble- $\mathrm{K}_{2} \mathrm{O}-\mathrm{K}, 21 \mathrm{mg}$ soluble-MgO-Mg per $100 \mathrm{~g}$, and 2.8\% of organic matter of air-dried soil $(0-30 \mathrm{~cm})$. These soil characteristics were obtained before starting the trial in April 2014. Fertilizers were not applied during the experimental period.

\subsection{Experiment Set Up}

In 2014, four $42 \mathrm{~m}$ long and $2.5 \mathrm{~m}$ wide experimental plots (replicates) were randomly arranged and tested with five different soil management practices: (i) herbicide; applied glyphosate throughout the inter-row area, $1.5 \mathrm{~L} /$ ha, every year in early May and late June; (ii) mulched soils with $1.2 \mathrm{~kg}$ of straw $/ \mathrm{m}^{2}$ in the first year of trial (2014) before the bud burst of the grapevine, and in the following years $(2015,2016)$ with $0.5 \mathrm{~kg} / \mathrm{m}^{2}$; (iii) tillage; inter-rows were cultivated in early April and late June to a depth of $15 \mathrm{~cm}$; (iv) natural permanent green cover; mowing green cover plants with a mulcher used five times in one season; and, (v) herbicide strips; applied herbicide in the same way as in the first above-mentioned treatment, but only within the row (vine-strip). All treatments were compared to a control plot (perennial meadow $15 \mathrm{~m}$ from the vineyard, which was mowed twice a year). Each of five soil management practices were randomly assigned to each plot (6 $\mathrm{m}$ long and $2.5 \mathrm{~m}$ wide). Between the treatments, $6 \mathrm{~m}$ long non treated areas were left to avoid any effect (Figure 1 ).
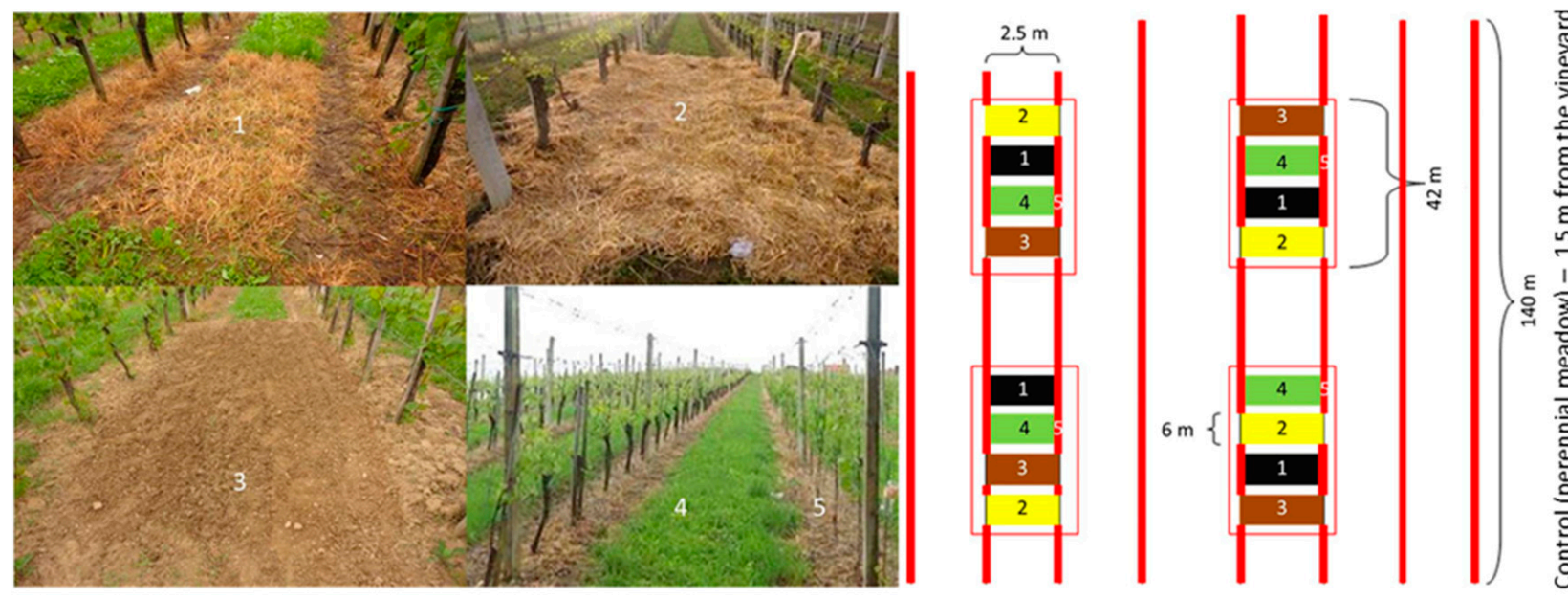

Figure 1. Different soil management practices. (1) herbicide, (2) mulch, (3) tillage, (4) green cover, (5) herbicide strip (left in the vineyard, right the experiment plan sketch). Picture is original (photo Marko Breznik). 


\subsection{Sampling and Measurements}

Sampling campaigns were conducted for three years (2014-2016), monitoring the abundance of earthworms (belonging to the Lumbricidae family) along with the soil profile at a depth from 0 to $60 \mathrm{~cm}$. At each sampling date, (22 May 2014, 9 August 2014, 13 October 2014, 13 June 2015, 17 May 2016, 15 June 2016 and 5 October 2016) pedological pits $\left(0.5 \times 0.5 \mathrm{~m}^{2}\right.$, depth $\left.0.6 \mathrm{~m}\right)$ were excavated in each treatment in four replicates. Each soil layer ( 0 to $15 \mathrm{~cm} 15$ to $30 \mathrm{~cm}, 30$ to $45 \mathrm{~cm}$ and 45 to $60 \mathrm{~cm}$ ) was separated into four foils, and the weight and number of earthworms (juvenile and adult), and their density in various layers per $\mathrm{m}^{2}$ were monitored. Manual sampling of earthworms from well-defined depths to a depth of $0.6 \mathrm{~m}$ is considered a sufficiently accurate method to estimate the size of earthworm populations [29]. The earthworms were classified by size into three categories: (i) small (up to $3 \mathrm{~cm}$ ), (ii) medium $(3$ to $6 \mathrm{~cm}$ ) and (iii) large (over $6 \mathrm{~cm}$ ). At each depth, the soil temperature was measured with a laser thermometer (IRT 39650-20, Cole-Parmer Instrument Co., Illinois, USA), and soil samples were taken to determine the gravimetric water content after drying for $48 \mathrm{~h}$ at $105^{\circ} \mathrm{C}$ [30].

\subsection{Statistical Analysis}

Before the analysis of variance, all parameters were tested for normality and variance homogeneity using the Levene test. For each sampling term, and between sampling terms and soil depths, one-way ANOVAs on earthworm biomass, density, and individual biomass were conducted. When the main effects were significant, mean comparisons between soil management methods were conducted using Tukey's test. The relationships between earthworm densities and soil moisture or biomass of earthworms were tested within treatments using Pearson correlations. The data were analysed using IBM SPSS Statistics software (vers. 25, IBM, Incorporation, Armonk, New York, NY, USA).

\section{Results and Discussion}

\subsection{Abundance and Biomass of Earthworm Community}

The impact of different soil management practices on the mean abundance and biomass of earthworms in different sampling terms is shown in Figure 2. In the first measurement period (22 May 2014), there was a significantly higher earthworm abundance in the mulch, control and green cover treatments compared to the herbicide strips $(p=0.035$, $p=0.021$ and $p=0.013$, respectively). During summer (9 August 2014), the abundance of the earthworm community slightly decreased in all treatments, except in the herbicide plots where, in addition to the control, it was significantly higher compared to the herbicide strip and tillage plot ( $p=0.003$ and $p=0.041$, respectively). This higher mean abundance of earthworms in the herbicide treatment at the start of the trial could be due to the increased mass of dead plant material (organic matter) present, which represents a large source of food for earthworms. Schreck [16] stated that such conditions can create favourable conditions for their reproduction. The abundance of earthworms in the herbicide strip plots was almost halved from spring to autumn. All treatments except tillage resulted in a significantly higher abundance of earthworms than in the herbicide strip $(p \leq 0.05)$.

In 2015, we performed only one sampling of earthworms (13 June 2015). In that year, most of the growing season registered water scarcity, apart from in May. In June 2015, there was less rainfall compared to 2014 and 2016. This coincided with a significantly lower abundance of the earthworm community, being the lowest in the herbicide strips and the highest in the control plots $(p=0.007)$. Compared to the treatments, most earthworms were located in the mulched plots, which clearly shows the positive effects of mulch on vineyard soils during dry conditions [30-32]. The treatments of green cover, herbicide, mulch and tillage did not differ significantly from each other $(p \leq 0.05)$. 


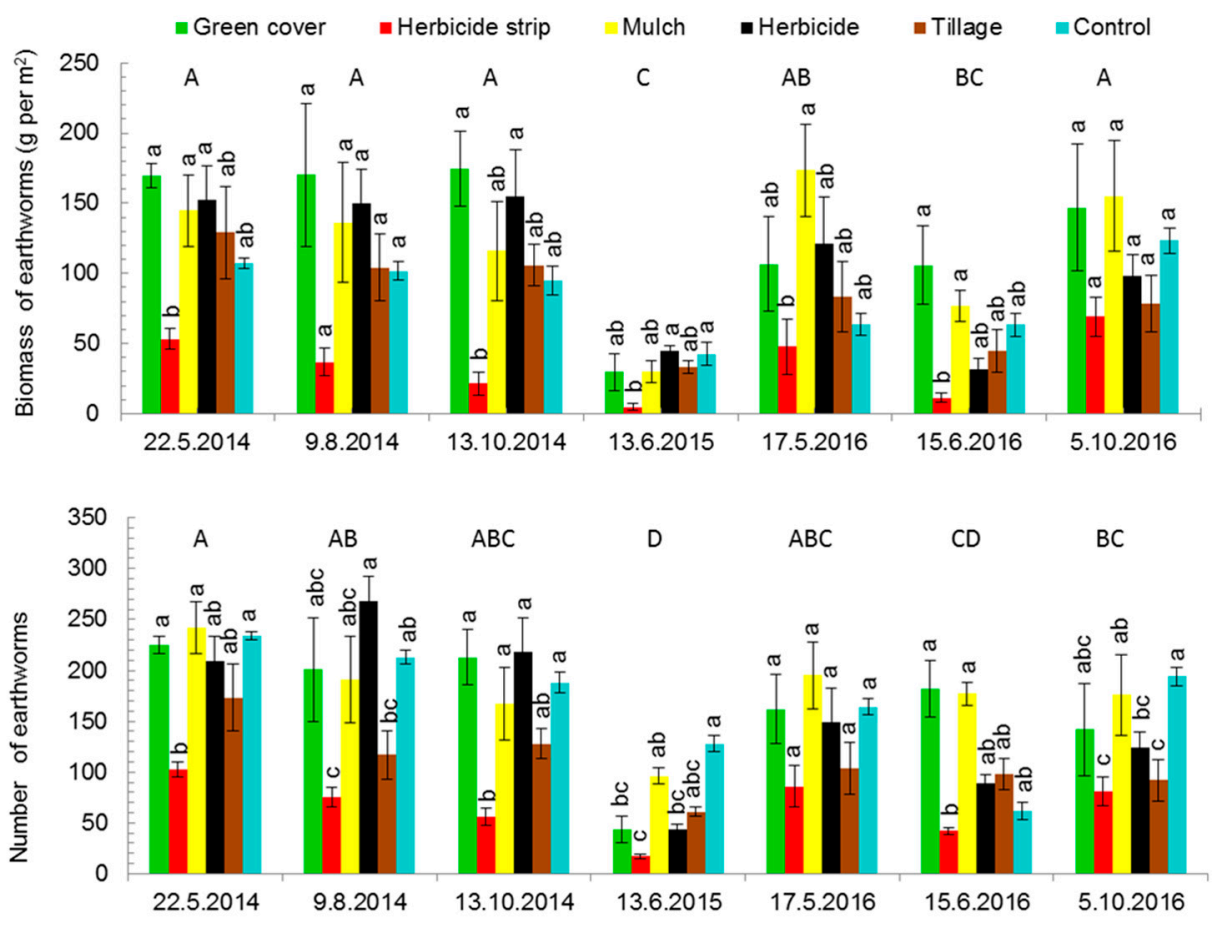

Figure 2. Abundance and fresh biomass ( $\mathrm{g}$ ) of earthworms per $\mathrm{m}^{2}$ according to different soil management practices in the vineyard from 2014 to 2016. Different lowercase letters denote significant differences among the soil management practices within the sampling term with $a>b>c$, and uppercase between the sampling terms $\mathrm{A}>\mathrm{B}>\mathrm{C}>\mathrm{D}(p \leq 0.05)$. Values are mean \pm standard error (SE), errors bars are SE.

At the beginning of the trial in 2016 (17 May), there were no significant differences among treatments $(p \leq 0.05)$. The lowest earthworm abundance was registered in the herbicide strip plot, with the highest in the mulch plot, and somewhat lower in the green cover plot. After one month (15 June 2016), there were similar dynamics; the lowest abundance was detected in the herbicide strip, the highest in the green cover $(p=0.036)$, and slightly lower in the mulched plot $(p=0.046)$. The abundance of the earthworm community almost halved in herbicide and tillage plots. In the last term (5 October 2016), after three years of experimentation, most earthworms were located on the meadow control, and significantly fewer in the cultivated soils $(p=0.030)$ and herbicide strips $(p=0.014)$. Throughout the experiment, the earthworm abundance was the most stable in the green cover and mulched plots. This agrees with Vršič [3], who states that there were three times more earthworms in green cover plots and mulch than in the cultivated soils. Chan [33] found using meta-analysis that the total earthworm abundance under no-tilled soils can be from two to nine times higher than with conventional tillage. In our experiment, on average, the highest abundance of earthworm community was obtained in the greencovered soil compared to other methods. This can be related to the benefits obtained with the availability of plant residue food [25,27]. Since earthworms were provided from different plant residues throughout the year in green cover and mulch, they can grow and proliferate more rapidly in these soils. As reported by other authors [e.g., 33], less disturbed systems are also key; thus, these factors can provide a good habitat for earthworm growth, with longer periods for feeding and cocoon production.

Earthworm abundance in the herbicide treatment was among the highest in the first year, but declined in the following years, possibly due to the reduction of the amount of food available for earthworms coinciding with the reduced vegetation cover. Deteriorating living conditions (higher soil temperature and lower soil water content) could also contribute to the reduction of earthworm abundance as reported by [29]. In the tillage plot, the mean earthworm abundance decreased from the beginning of the experiment to the end. Similar 
findings were found by Schreck, Andersen, and Ernest [16,26,34] in an apple orchard plantation. Dekemati [12] also found significantly higher earthworm abundance in notillage soil compared to ploughed soils, and in reduced and conventional tillage treatments. Our hypothesis, i.e., that green cover and mulch would have the highest earthworm abundances compared to the other treatments (herbicide and tillage), was justified.

Often the size of the earthworm community, expressed by the number of specimens, does not reflect the current condition of the soil because it does not include the size of earthworms. Depending on their size, earthworms have different effects on the soil [29]. In our experiment, there was a strong correlation between the mean abundance and biomass of earthworms $(r=0.85)$, so that the earthworm abundance in most cases coincided with their biomass (Figure 3). At the beginning of the experiment, the mean biomass of earthworms was the highest in the green cover, and slightly lower in the herbicide and mulch plots, and almost three times higher as in the herbicide strip plot $(p=0.008, p=0.028$ and $p=0.048$, respectively). In the second term, the values remained at a similar level, but the differences were not significant. At the end of the experiment during the first year (13 October 2014), the mean biomass of earthworms in the herbicide and green cover were $4.2(p=0.011)$ and $4.7(p=0.003)$ times higher than in the herbicide strip, respectively.

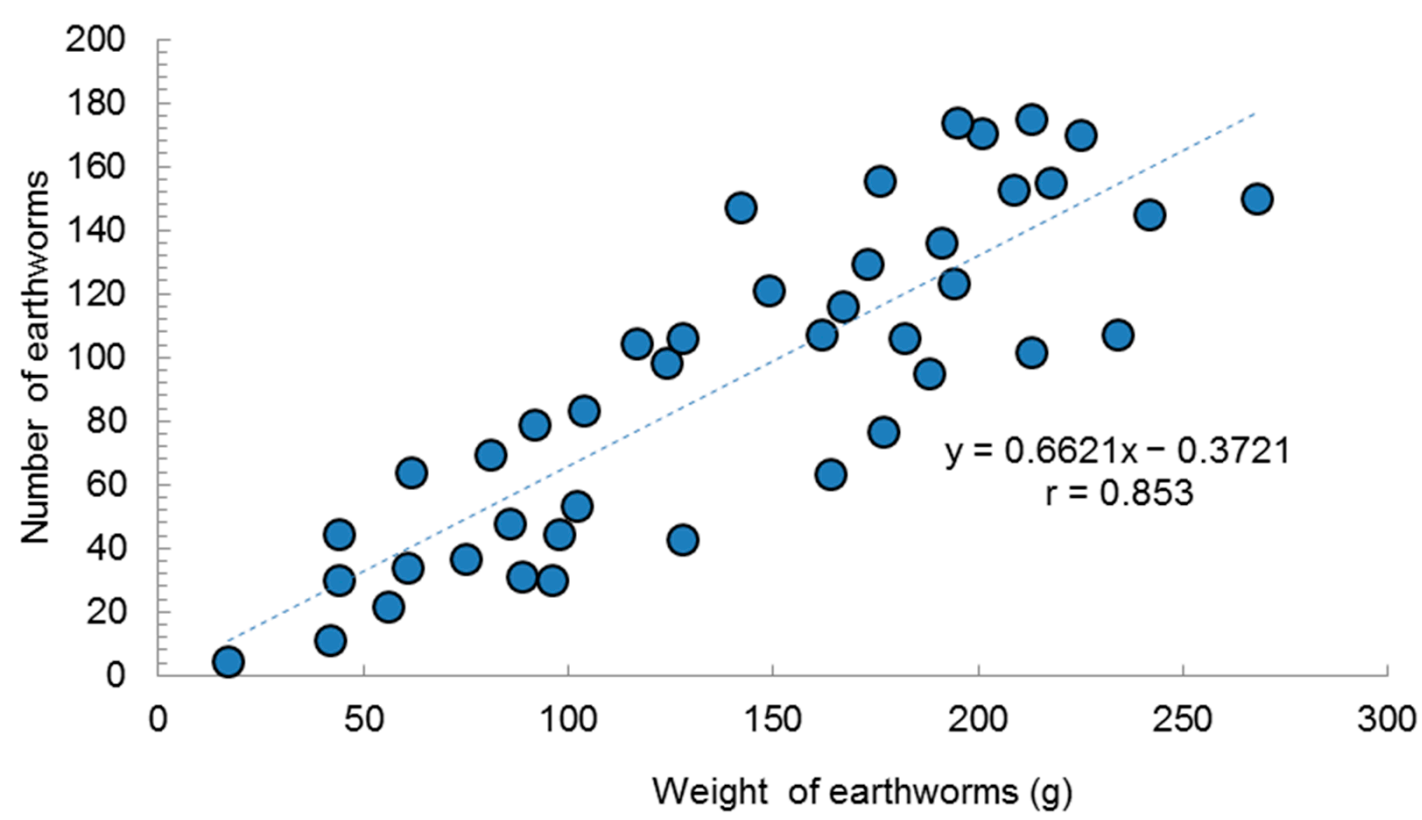

Figure 3. The connection between abundance and biomass of earthworms within treatments (2014-2016; $p=0.001)$.

Like abundance, earthworm biomass confirms that soil moisture has a major impact on earthworm development. Due to the drought conditions in 2015, especially in the spring, the biomass of earthworms was significantly lower compared to 2014, with above-average rainfall $(p<0.0001$; Figure 2), but the ratio in biomass between the soil management practices was even higher. The mean biomass of earthworms in herbicide $(p=0.016)$ or in control $(p=0.023)$ plots was almost 10 times higher than in the herbicide strip. In the case of mulch, the mean biomass of earthworms was $30 \mathrm{~g} / \mathrm{m}^{2}$. Even though the mean biomass of earthworms in the mulch plot was lower compared to the herbicide plot, the mean abundance of earthworms was twice as high $\left(96 / \mathrm{m}^{2}\right)$ as in the herbicide plots $\left(44 / \mathrm{m}^{2}\right)$.

In 2016, from the first to the third term, the lowest mean biomass of earthworms was in the herbicide strip. In the first term, there was a significantly higher mean biomass in the mulched plot $(p=0.041)$, in the second in the green cover $(p=0.036)$, and in the third period the differences were not significant. The highest value was registered in the mulch $\left(155.2 \mathrm{~g} / \mathrm{m}^{2}\right)$ and green cover $\left(146.9 \mathrm{~g} / \mathrm{m}^{2}\right)$ soils. De Vetter [27] also observed this using straw mulch. 
Permanent green cover and mulching had a favourable effect on the mean biomass of earthworms, better than the control (meadow), except in the driest year of 2015. With the treatment of herbicides, there was initially a higher mean biomass of earthworms, but it decreased from the first term from $152.6 \mathrm{~g} / \mathrm{m}^{2}$ to $98.4 \mathrm{~g} / \mathrm{m}^{2}$. Correia [35] confirmed that the biomass of earthworms in soil treated with glyphosate was halved and the earthworms remained alive in the soil at all stages of development, but their biomass decreased. This was similar to the tillage plot, except that the mean biomass was slightly higher at the beginning and at the end of the experiment) compared to the herbicide strip. However, the availability of organic matter was lower in both cases, which can affect the biomass of earthworms [25].

From the mean abundance and biomass of earthworms during the entire experimental period (from 22 May 2014 to 5 October 2016), we can conclude that different soil management practices had significant effects $(p \leq 0.05)$ on both parameters of the earthworm community (Table 1). On average, the lowest earthworm abundance was in the herbicide strip with a mean biomass of $34.9 \mathrm{dt} \mathrm{ha}^{-1}$. Significantly larger earthworm communities were in the permanent green cover, mulch and control plots compared to the herbicide strip $(p<0.0001)$ and tillage $(p=0.024, p=0.004$ and $p=0.017$, respectively). Schreck [16] also reported that mechanical weeding dramatically decreases the biomass of earthworms in the vineyard. The use of different soil tillage methods [11] was not found to decrease the earthworm abundance. The mean biomass of earthworms was significantly higher in the permanent green cover compared to the herbicide strip $(p<0.0001)$, tillage $(p=0.030)$ and control ( $p=0.048)$ plots. The mean biomass of earthworms in the permanent green cover was $12.9 \mathrm{dt} \mathrm{ha}^{-1}$ and in the mulch $11.9 \mathrm{dt} \mathrm{ha}^{-1}$, which is $56 \%$ and $44 \%$ higher, respectively, then in the tillage soils $\left(8.3 \mathrm{dt} \mathrm{ha}^{-1}\right)$. Similar dynamics in vineyards and orchards were also reported by Paoletti [36]. In the herbicide strip, the mean biomass of earthworm was only a third of that in a permanent greening treatment.

Table 1. Abundance and biomass ( $\mathrm{g}$ ) of earthworms per $\mathrm{m}^{2}$ in soil with different soil management practices in the period from 22 May 2014 to 5 October 2016.

\begin{tabular}{ccccc}
\hline \multirow{2}{*}{ Soil Management System } & \multicolumn{2}{l}{ Number of Earthworms } & \multicolumn{2}{c}{ Weight of Earthworms } \\
\cline { 2 - 5 } & Average \pm SE & \multicolumn{3}{c}{ Average \pm SE } \\
\hline Green cover & $167 \pm 14.2$ & $\mathrm{a}$ & $129.19 \pm 14.42$ & $\mathrm{a}$ \\
Herbicide strip & $66 \pm 7.18$ & $\mathrm{C}$ & $34.89 \pm 5.56$ & $\mathrm{c}$ \\
Mulch (straw) & $178 \pm 14.57$ & $\mathrm{a}$ & $118.94 \pm 13.56$ & $\mathrm{ab}$ \\
Herbicide & $157 \pm 17.13$ & $\mathrm{ab}$ & $107.54 \pm 12.03$ & $\mathrm{ab}$ \\
Tillage & $110 \pm 9.71$ & $\mathrm{bc}$ & $82.73 \pm 9.37$ & $\mathrm{~b}$ \\
Control & $169 \pm 11.04$ & $\mathrm{a}$ & $85.27 \pm 5.80$ & $\mathrm{~b}$ \\
\hline
\end{tabular}

Different letters denote significant differences among soil management practices with $\mathrm{a}>\mathrm{b}>\mathrm{c}(p \leq 0.05)$; values are mean \pm standard error (SE).

\subsection{Earthworm Abundance and Biomass at Different Soil Depths}

In the third year of the experiment (2016), the density of earthworms was also determined according to the soil depth, considering different layers (Figure 4). About two-thirds of the earthworms were distributed in the first $15 \mathrm{~cm}$ (from $64.1 \%$ in the herbicide to $69.7 \%$ in the mulched plot). In the mulched plot there were almost twice as many earthworms as in the tilled soils. The lowest amount was found in the herbicide strip. A total of $13.3 \%$ was reached in the mulch and tillage plots from 15 to $30 \mathrm{~cm}$. In this soil layer, $25.5 \%$ of the total abundance was found in the control plot. At a depth of 30-60 cm the earthworm abundance was $8.1 \%$ in the herbicide strip and control plots and reached $20.4 \%$ in the tilled soils. This means that when tillage machines or herbicides are used, the earthworms are homogeneously distributed along with the upper layers. Several authors attribute this fact to the increase in bulk density and soil compaction, affecting soil porosity, aeration, as well as loss of nutrients and organic carbon $[2,37,38]$. 

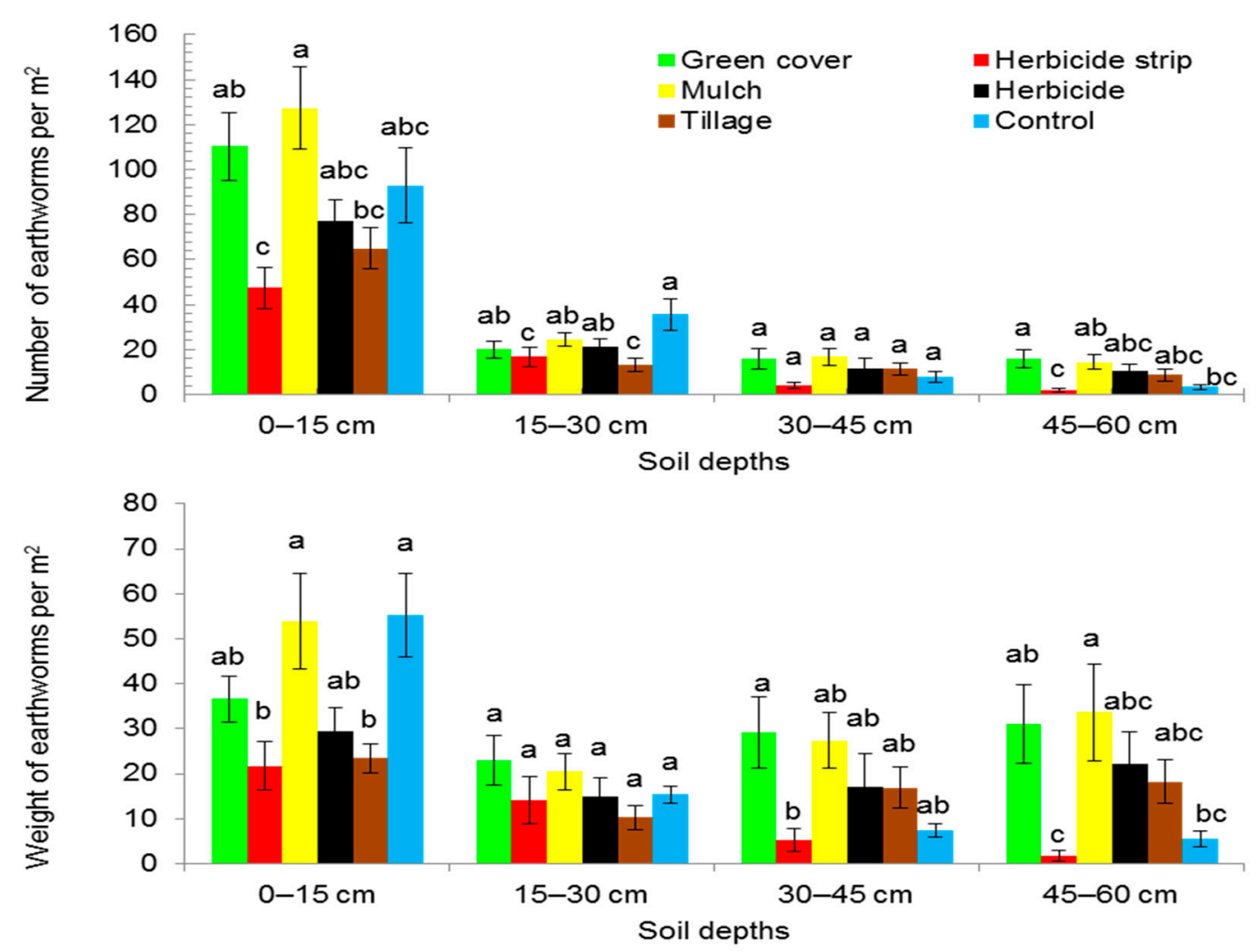

Figure 4. Earthworm abundance and their biomass at different soil depths per $\mathrm{m}^{2}$ according to different soil management practices during the last year of the trial. Different letters denote significant differences among soil management practices in each depth $(p \leq 0.05)$, error bars are standard errors.

Considering the biomass of the earthworms at different soil depths, we observed slightly different relationships compared to their density (Figure 4). The biomass of earthworms at a depth up to $15 \mathrm{~cm}$ was most proportional to their amount in the control plot; $66.4 \%$ of density represented $66.2 \%$ of the biomass. The other treatments also had a similar proportion of earthworm density at this depth, from $64.1 \%$ in the herbicide to $69.7 \%$ in the mulch, but their amounts represented from $30.5 \%$ in green cover to $50.7 \%$ of earthworm biomass in the herbicide strip. The highest biomass of earthworms was found in the mulch and green cover plots. Although there were $20 \%$ or fewer earthworms at a depth of 30- $60 \mathrm{~cm}$, except in the control and herbicide strips (8.1\%), their biomass in these soil layers represented about $50 \%$ of the earthworm community, except in the control $(15.4 \%)$ and the herbicide strip $(16.4 \%)$ plots. This means that in the case of mulch, green cover, tillage, and herbicide plots, the biomass of earthworms was more or less evenly distributed to a depth up to $60 \mathrm{~cm}$, which could not be confirmed by their abundance. Although ecological categories were not assessed in the current experiment, the mean biomass of individual earthworms increased from the top to the bottom of the soil profile except in the herbicide strip (Figure 5). The highest mean biomass of individuals in the first layer was found in the control plot $(748 \mathrm{mg})$. In the next two soil layers, the highest mean values were $1183 \mathrm{mg}$ and $2092 \mathrm{mg}$, respectively, corresponding to the green cover plot. Finally, in the last surveyed layer, $1842 \mathrm{mg}$ was the highest, which was found in the mulched soils. Along with the soil profile, on average, the largest earthworms were found in the green cover plots (1329 mg per ind.) and the lowest ones in the herbicide strip plots (502 mg per ind.). The relationships between biomass and abundance of earthworms per $\mathrm{m}^{2}$ were different according to the soil layer (Figure 6). The correlation was higher in the second part of the studied profile, which was also confirmed by the fact that at a depth of $30-60 \mathrm{~cm}$ the majority of earthworm biomass was represented by larger specimens, except in the herbicide strip at the fourth depth (Figure 5). The most likely reason for this is that 
larger species are located deeper in the soil, as stated by Jiménez [39]. The mature worms of some species are located deeper in the soil than the immature worms [15].

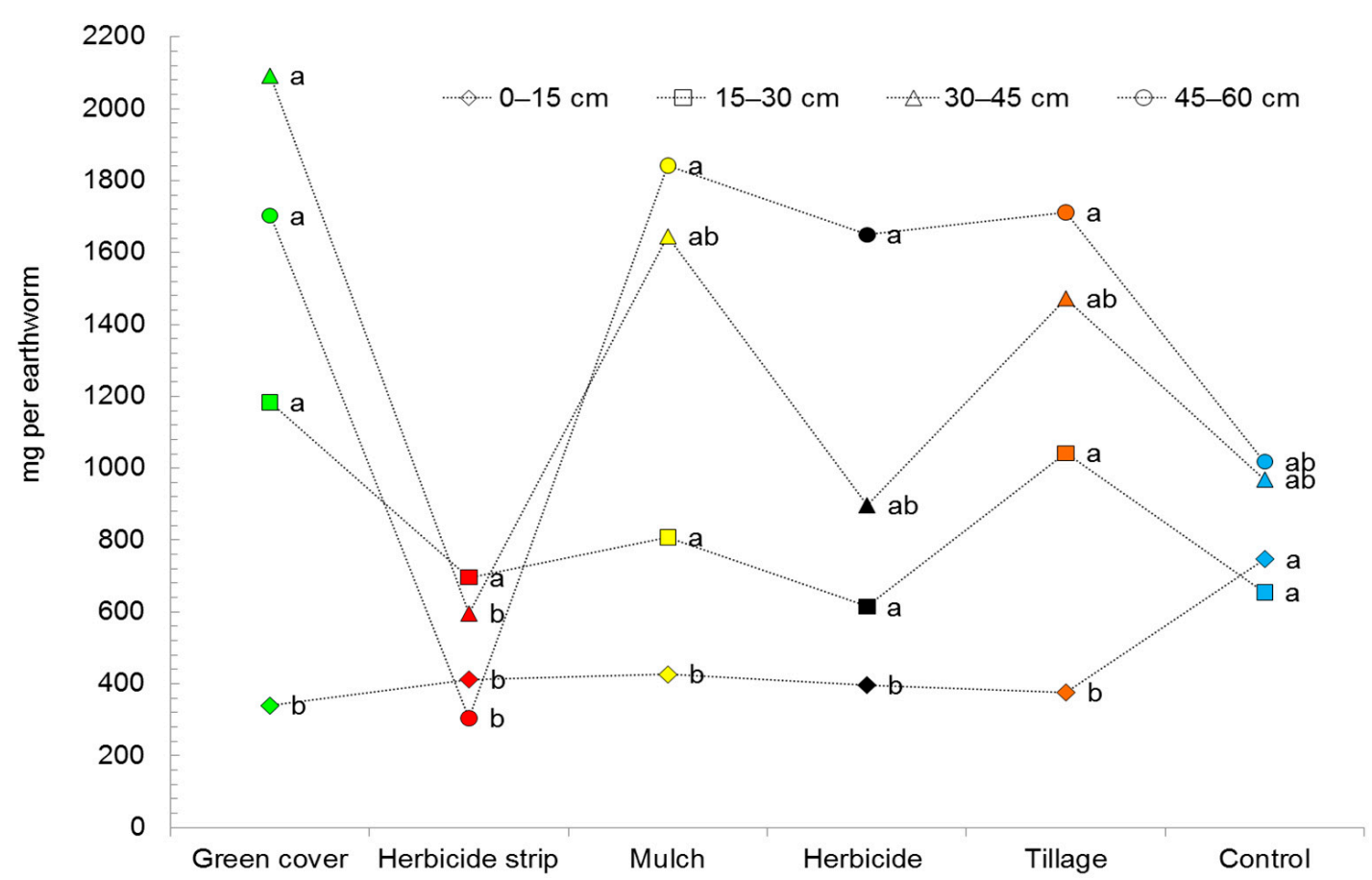

Figure 5. Mean biomass of individual adult earthworms per $\mathrm{m}^{2}$ at different soil depths according to different soil management practices. Different letters denote significant differences among soil management practices in each depth $(p \leq 0.05)$.
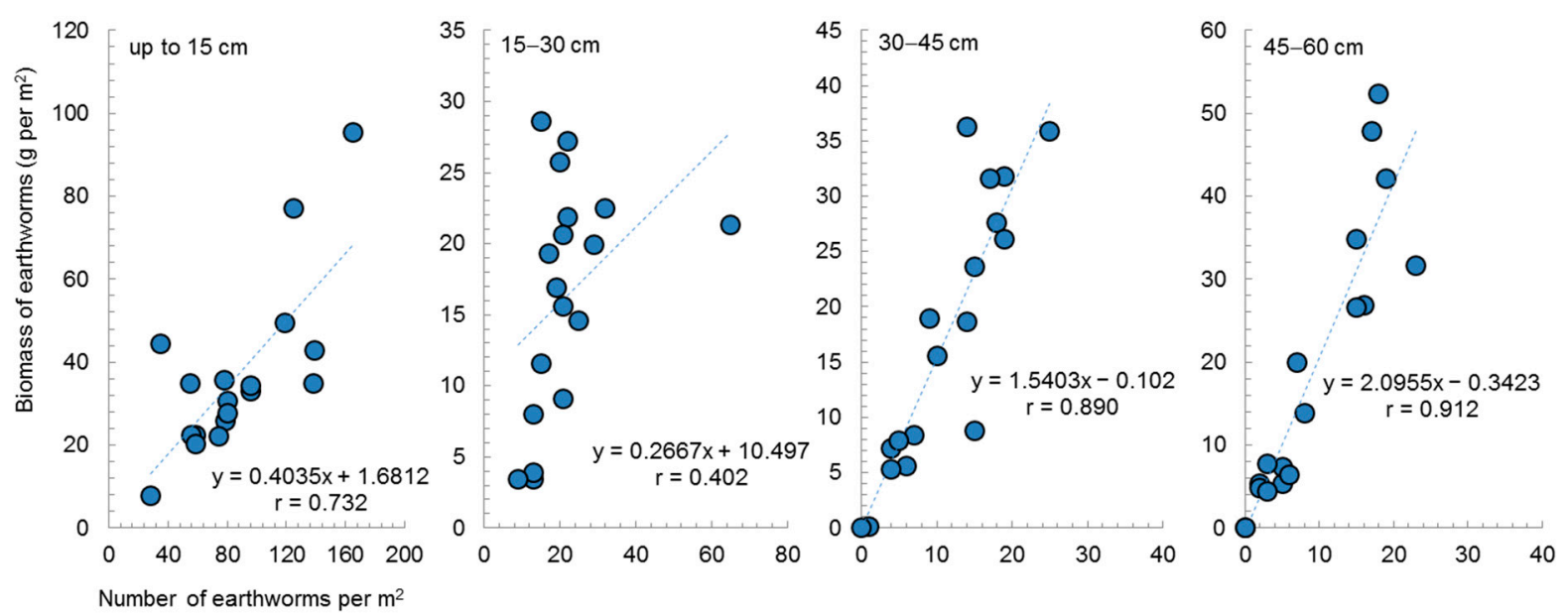

Figure 6. Relationship between mean biomass and number of earthworms per $\mathrm{m}^{2}$ at different soil depths (in all depths $p=0.001$, except 15-30 $\mathrm{cm} p=0.038$ ) according to different soil management practices in vineyard; $\mathrm{r}-$ Pearson correlation index.

\subsection{Soil Temperature and Moisture}

In the third year of the trial (2016) at each depth, at the same time as the earthworm abundance was monitored, soil temperature and moisture were also measured. The mean soil temperature and moisture in Spring samples 2016 (Figure 7), considering the different soil management practices, were significantly different in the first depths $(p \leq 0.05)$ during the survey. The lowest temperature $\left(19.2{ }^{\circ} \mathrm{C}\right)$ and highest moisture $(20.3 \%)$ was registered in the mulched plot. Higher temperature and lower moisture were registered in treatments where the soil was more exposed to solar radiation (herbicide, tillage, herbicide strip). 
Earthworms had good conditions in the Spring for their activities and reproduction in green cover, mulch and control plots. Differences in temperature, especially in the upper layer, may have influenced the development of earthworms. Viljoen [40] found that the highest maturation rate of earthworms was obtained at 22 and $25^{\circ} \mathrm{C}$, which were the optimal temperatures for cocoon production. They also noted that although higher temperatures favoured growth, fecundity would be higher at this range. Upper lethal temperatures of earthworms typically range between 25 and $35^{\circ} \mathrm{C}$ but vary substantially among species [41].
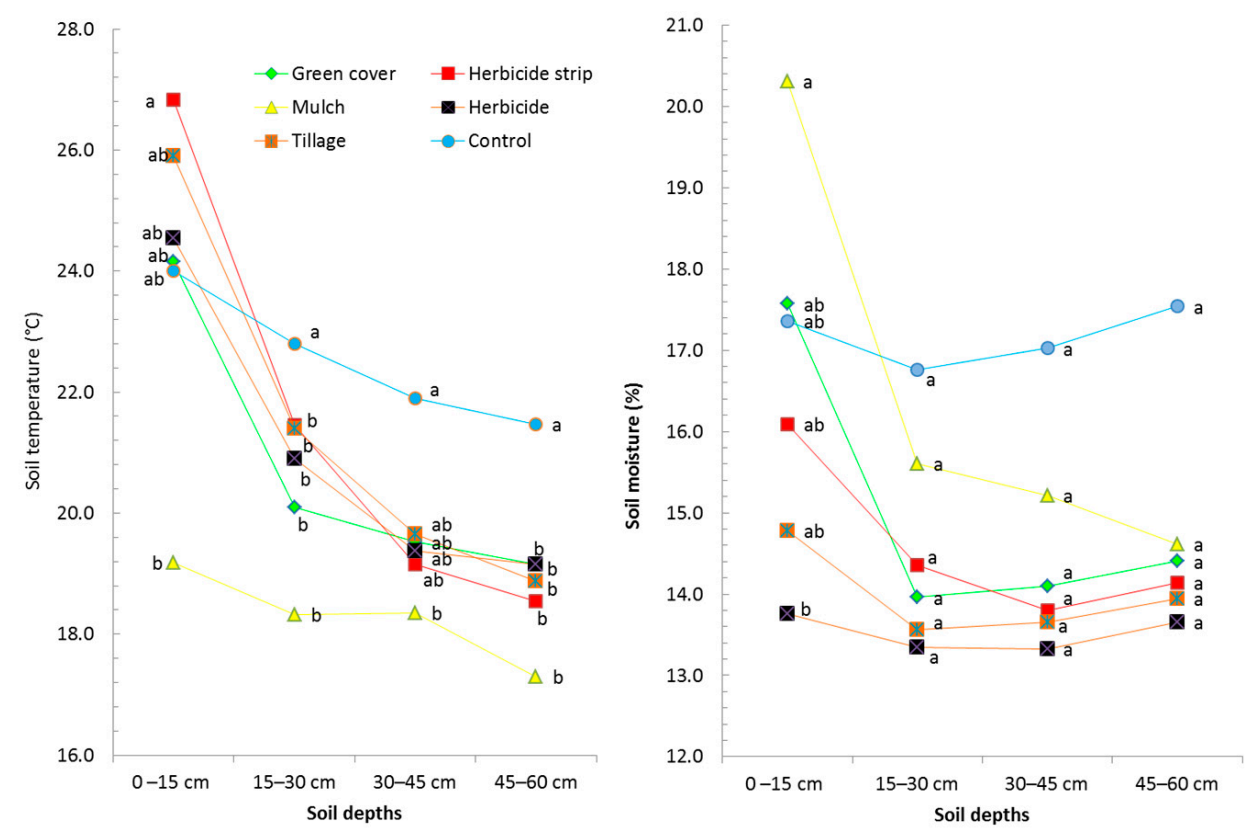

Figure 7. Mean soil temperature and moisture of spring samples in the third year of the trial along with the soil profile at depths from 0 to $60 \mathrm{~cm}$. according to different soil management practices. Different letters denote significant differences among soil management practices in each depth $(p \leq 0.05)$.

In the following layers of the soil profile up to $60 \mathrm{~cm}$, the differences were lower. Due to the higher water content in covered soils, more energy is needed to heat the soil, but the reason for the lower soil temperature under the mulch is also that straw has a low thermal conductivity and heat transfer from the atmosphere to the soil and vice versa [20].

The influence of soil moisture on earthworm abundance was found along with the soil profile at depths from 0 to $60 \mathrm{~cm}$ during the survey (Figure 8). With the increase in soil moisture, the abundance and biomass of earthworms $(\mathrm{r}=0.776 ; p=0.001$ and $\mathrm{r}=0.625$; $p=0.011$, respectively) increased, while the biomass of individual earthworms decreased $(r=-0.496 ; p=0.028)$. From the first to the fourth soil layer these relationships weakened. The highest share of this connection was represented in data from the first half of the profile $(0-30 \mathrm{~cm})$, both in number $(r=0.833)$ and the biomass of earthworms $(r=0.891)$. Soil moisture had an important effect on the vertical distribution of earthworms as stated by Fründ [42], but these temperature connections could not be confirmed. Wever, Berry, and Eriksen-Hammel [43-45] stated that the greatest increase in earthworm biomass was found in soil with $25-30 \%$ moisture and $15-20{ }^{\circ} \mathrm{C}$. The correlations between earthworm parameters, soil moisture and temperature, according to the different soil management practices, are in Table 2. 

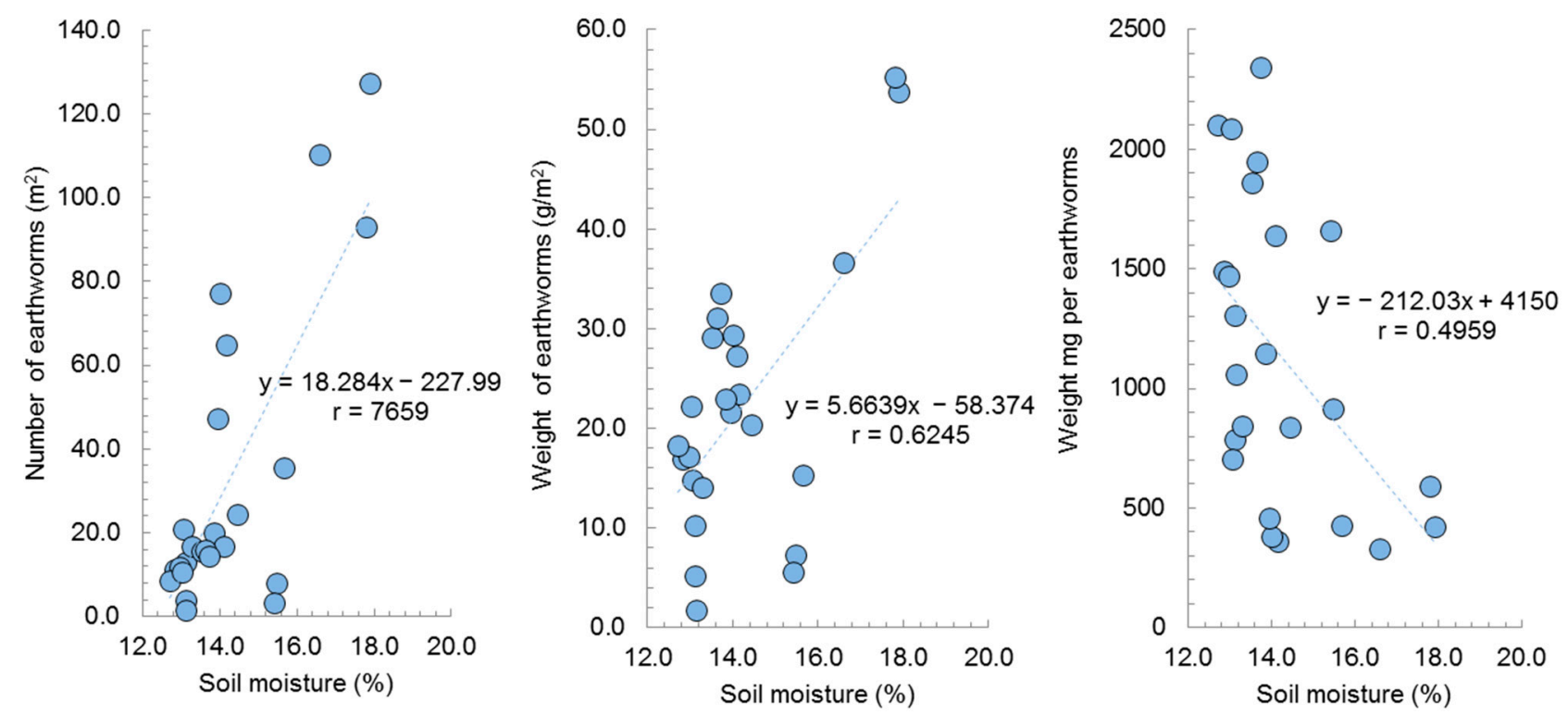

Figure 8. Relationship between mean soil moisture and the mean number and weight of earthworms along with the soil profile at depths from 0 to $60 \mathrm{~cm}$; r-Pearson correlation index.

Table 2. Correlations between earthworm parameters and soil moisture and temperature according to different soil management practices along with the soil profile at depths from 0 to $60 \mathrm{~cm}$.

\begin{tabular}{|c|c|c|c|c|c|c|c|c|c|}
\hline \multirow{2}{*}{ Earthworms } & \multirow{2}{*}{$\begin{array}{c}\text { Soil Management } \\
\text { Practices/Depth } \\
\text { of Soil }\end{array}$} & \multicolumn{4}{|c|}{$\begin{array}{l}\text { Pearson Correlation } \\
\text { (Soil Moisture) }\end{array}$} & \multicolumn{4}{|c|}{$\begin{array}{l}\text { Pearson Correlation } \\
\text { (Soil Temperature) }\end{array}$} \\
\hline & & $\mathrm{Up}$ to $15 \mathrm{~cm}$ & $15-30 \mathrm{~cm}$ & $30-45 \mathrm{~cm}$ & $45-60 \mathrm{~cm}$ & Up to $15 \mathrm{~cm}$ & $15-30 \mathrm{~cm}$ & $30-45 \mathrm{~cm}$ & $45-60 \mathrm{~cm}$ \\
\hline \multirow{6}{*}{ Number $/ \mathrm{m}^{2}$} & Green cover & -0.418 & 0.223 & -0.518 & 0.138 & -0.056 & -0.038 & 0.740 ** & 0.237 \\
\hline & Herbicide strip & 0.346 & -0.302 & 0.167 & 0.476 & 0.063 & 0.127 & -0.141 & 0.425 \\
\hline & Mulch & -0.157 & -0.034 & -0.207 & 0.461 & 0.095 & 0.069 & $0.842^{* * *}$ & -0.07 \\
\hline & Herbicide & -0.131 & 0.359 & 0.362 & 0.803 ** & -0.398 & 0.466 & $0.865^{* * *}$ & 0.489 \\
\hline & Tillage & -0.527 & 0.468 & 0.392 & 0.354 & -0.357 & 0.083 & 0.466 & -0.099 \\
\hline & Control & $0.840 * * *$ & $0.879 * * *$ & $0.651 *$ & 0.232 & $0.826^{* *}$ & $0.906^{* * *}$ & 0.403 & 0.511 \\
\hline \multirow{6}{*}{ Biomass $/ \mathrm{m}^{2}$} & Green cover & -0.454 & -0.096 & -0.435 & -0.212 & 0.096 & -0.281 & 0.740 ** & 0.532 \\
\hline & Herbicide strip & 0.437 & -0.121 & -0.096 & 0.131 & 0.171 & 0.229 & -0.258 & 0.562 \\
\hline & Mulch & 0.356 & -0.357 & -0.194 & 0.393 & 0.087 & -0.034 & $0.805^{* *}$ & 0.141 \\
\hline & Herbicide & -0.11 & 0.572 & 0.151 & 0.694 & 0.299 & 0.534 & $0.739 * *$ & 0.342 \\
\hline & Tillage & -0.517 & 0.071 & 0.303 & 0.394 & -0.193 & 0.002 & 0.292 & 0.054 \\
\hline & Control & $-0.893^{* * *}$ & $0.888^{* * *}$ & 0.511 & -0.001 & -0.700 * & $0.939^{* * *}$ & 0.253 & 0.343 \\
\hline \multirow{6}{*}{$\begin{array}{l}\text { Weight per } \\
\text { individual }\end{array}$} & Green cover & -0.366 & -0.459 & 0.181 & -0.101 & 0.094 & -0.468 & 0.038 & 0.583 \\
\hline & Herbicide strip & -0.25 & 0.086 & 0.101 & 0.172 & -0.417 & -0.006 & 0.086 & 0.465 \\
\hline & Mulch & $0.692^{*}$ & $-0.676^{*}$ & 0.016 & 0.294 & 0.117 & 0.007 & -0.192 & 0.304 \\
\hline & Herbicide & 0.044 & $0.646^{*}$ & 0.404 & 0.016 & $0.724^{* *}$ & 0.704 * & 0.583 & 0.213 \\
\hline & Tillage & -0.197 & 0.05 & -0.071 & 0.587 & 0.058 & 0.408 & -0.194 & 0.455 \\
\hline & Control & $-0.859 * * *$ & -0.299 & -0.154 & -0.296 & $-0.931 * * *$ & -0.253 & -0.195 & 0.083 \\
\hline
\end{tabular}

$* * *$ and ${ }^{* * *}$ indicate significance at the $0.10,0.05$ and 0.01 levels, respectively.

\section{Conclusions}

Different soil management practices in the vineyard affected soil moisture and temperature, indicating significant differences in earthworm abundance and their distribution by soil profile. The highest soil temperatures and the lowest soil moisture at a depth of $15 \mathrm{~cm}$ were recorded in the treatments where the soil was more exposed to solar radiation (herbicide, herbicide strip, and shallow tillage). On average, at all depths, the lowest temperature was in the mulched plot, and the soil moisture was the highest compared to other soil treatments, except the control (meadow). This is because straw reflects more sunlight into the atmosphere, causing less solar energy to be absorbed into the soil. In the soil with a permanent green cover there was slightly lower soil moisture than in the mulched soil. The earthworm abundance was highest in permanent green cover and mulch (higher 
than in control), which provided favourable conditions for earthworm development. At the beginning of the experiment, the abundance of the earthworm community was also similar in the herbicide plot (over the entire surface). This can be related to the benefits obtained by the rapid availability of plant residue food (organic matter). Towards the end of the experiment, however, the abundance began to decline in this treatment, indicating a deterioration in soil conditions. The lowest mean earthworm abundance and biomass per individual were found in the herbicide strip. Although no toxicity was detected in this experiment, it could be concluded that the use of glyphosate adversely affects the development of earthworms. Shallow tillage also harmed earthworms, as their abundance decreased during this experiment due to disturbances in habitat and deterioration of natural conditions. The differences in the abundance of the earthworm community according to the different soil management practices showed that earthworms are good bioindicators for the assessment of soil fertility and sustainable land use, and for monitoring the efficiency of ecosystem services in viticulture. According to the hypothesis, permanent green covering and straw mulch proved to be the most suitable soil management practices for earthworms in vineyards in the continental part of Slovenia. Long-term use of herbicides had a very negative effect on earthworms that was slightly less in its effect than soil tillage. However, the most commonly used soil management practice (green cover) will have to be adapted to climate change in the future. Less precipitation and higher temperatures have a negative impact on the development of earthworms, which, in addition to difference between treatments, was also confirmed by the differences between sampling terms. Alternating tillage in the vineyard is possible every second inter-row space, which would allow repopulation of earthworms in the disturbed inter-rows from neighbouring vegetated inter-rows.

Author Contributions: Conceptualisation. S.V. and M.B.; methodology. S.V. and B.P.; formal analysis. B.P.; investigation. M.B.; writing-Original draft preparation. S.V.; writing-Review and editing. J.R.-C.; funding acquisition. S.V. All authors have read and agreed to the published version of the manuscript.

Funding: This research was funded by the University Centre of Viticulture and Enology Meranovo, Faculty of Agriculture and Life Sciences.

Institutional Review Board Statement: The study was conducted according to the guidelines of the Declaration of Helsinki, and approved by the study commission of the Faculty of Agriculture and Life Sciences in 2020.

Data Availability Statement: Data are available at the University of Maribor (https://dk.um.si/ Dokument.php?id=142381, accessed on 19 June 2021) and UC of viticulture and enology Meranovo.

Acknowledgments: The authors would like to thank the University centre of viticulture and enology, Faculty of Agriculture and Life Sciences for their financial support of this research. The authors are also grateful for the hard physical work of a group of technical assistants and students, which was necessary for the establishment of these perennial trials.

Conflicts of Interest: The authors declare no conflict of interest. The funders had no role in the design of the study; in the collection, analyses, or interpretation of data, in the writing of the manuscript, or in the decision to publish the results.

\section{References}

1. Bagagiolo, G.; Biddoccu, M.; Rabino, D.; Cavallo, E. Effects of rows arrangement, soil management, and rainfall characteristics on water and soil losses in Italian sloping vineyards. Environ. Res. 2018, 166, 690-704. [CrossRef] [PubMed]

2. Novara, A.; Stallone, G.; Cerdà, A.; Gristina, L. The Effect of Shallow Tillage on Soil Erosion in a Semi-Arid Vineyard. Agronomy 2019, 9, 257. [CrossRef]

3. Vršič, S. Soil erosion and earthworm population responses to soil management systems in steep-slope vineyards. Plant Soil Environ. 2011, 57, 258-263. [CrossRef]

4. Rodrigo-Comino, J. Five decades of soil erosion research in "terroir". The State-of-the-Art. Earth-Sci. Rev. 2018, 179, 436-447. [CrossRef]

5. Hofmann, M.; Schultz, H.R. Erratum to: Modeling the water balance of sloped vineyards under various climate change scenarios. BIO Web Conf. 2015, 5, 01027. [CrossRef] 
6. Serpa, D.; Nunes, J.; Keizer, J.; Abrantes, N. Impacts of climate and land use changes on the water quality of a small Mediterranean catchment with intensive viticulture. Environ. Pollut. 2017, 224, 454-465. [CrossRef]

7. Riches, D.; Porter, I.; Oliver, D.; Bramley, R.; Rawnsley, B.; Edwards, J.; White, R. Review: Soil biological properties as indicators of soil quality in Australian viticulture. Aust. J. Grape Wine Res. 2013, 19, 311-323. [CrossRef]

8. Bruggisser, O.T.; Schmidt-Entling, M.H.; Bacher, S. Effects of vineyard management on biodiversity at three trophic levels. Biol. Conserv. 2010, 143, 1521-1528. [CrossRef]

9. Nicholls, C.I.; Parrella, M.; Altieri, M.A. The effects of a vegetational corridor on the abundance and dispersal of insect biodiversity within a northern California organic vineyard. Landsc. Ecol. 2001, 16, 133-146. [CrossRef]

10. Orgiazzi, A.; Panagos, P. Soil biodiversity and soil erosion: It is time to get married. Glob. Ecol. Biogeogr. 2018, $27,1155-1167$. [CrossRef]

11. Florian, F.; Elisabeth, W.; Zaller, J.G. Earthworms are little affected by reduced soil tillage methods in vineyards. Plant Soil Environ. 2017, 63, 257-263. [CrossRef]

12. Dekemati, I.; Simon, B.; Vinogradov, S.; Birkás, M. The effects of various tillage treatments on soil physical properties, earthworm abundance and crop yield in Hungary. Soil Tillage Res. 2019, 194, 104334. [CrossRef]

13. Pérès, G.; Piron, D.; Bellido, A.; Goater, C.; Cluzeau, D. Earthworms Used as Indicators of Agricultural Managements. Fresenius Environ. Bull. 2008, 17, 1181-1189.

14. Coll, P.; Le Cadre, E.; Blanchart, E.; Hinsinger, P.; Villenave, C. Organic viticulture and soil quality: A long-term study in Southern France. Appl. Soil Ecol. 2011, 50, 37-44. [CrossRef]

15. Fründ, H.-C.; Graefe, U.; Tischer, S. Earthworms as Bioindicators of Soil Quality. Soil Biol. 2011, 24, 261-278. [CrossRef]

16. Schreck, E.; Gontier, L.; Dumat, C.; Geret, F. Ecological and physiological effects of soil management practices on earthworm communities in French vineyards. Eur. J. Soil Biol. 2012, 52, 8-15. [CrossRef]

17. Kavdir, Y.; Ilay, R. Earthworms and Soil Structure. Soil Biol. 2010, 24, 39-50. [CrossRef]

18. Blouin, M.; Hodson, M.; Delgado, E.A.; Baker, G.L.; Brussaard, L.; Butt, K.R.; Dai, J.; Dendooven, L.; Peres, G.; Tondoh, J.E.; et al. A review of earthworm impact on soil function and ecosystem services. Eur. J. Soil Sci. 2013, 64, 161-182. [CrossRef]

19. Arai, M.; Miura, T.; Tsuzura, H.; Minamiya, Y.; Kaneko, N. Two-year responses of earthworm abundance, soil aggregates, and soil carbon to no-tillage and fertilization. Geoderma 2018, 332, 135-141. [CrossRef]

20. White, R.E. Understanding Vineyard Soils: Site Selection and Soil Preparation; Oxford University Press: New York, NY, USA, 2015; pp. 30-66.

21. Shuster, W.D.; McDonald, L.P.; McCartney, D.A.; Parmelee, R.W.; Studer, N.S.; Stinner, B.R. Nitrogen Source and Earthworm Abundance Affected Runoff Volume and Nutrient Loss in a Tilled-Corn Agro Ecosystems. Biol. Fertil. Soils 2002, 35, 320-327. [CrossRef]

22. Safeer, A.; Aziz, I.; Mahmood, T.; Akmal, M. Influence of Different Tillage Practices and Earthworm on Selected Soil PhysioChemical Parameters and Yield of Maize. Soil Environ. 2013, 32, 114-120.

23. Zaller, J.; Arnone, J. Earthworm and soil moisture effects on the productivity and structure of grassland communities. Soil Biol. Biochem. 1999, 31, 517-523. [CrossRef]

24. Foth, H. Fundamentals of Soil Science: Soil Ecology, 8th ed.; John Wiley and Sons: New York, NY, USA, 1990; pp. 115-132.

25. Pérès, G.; Cluzeau, D.; Curmi, P.; Hallaire, V. Earthworm activity and soil structure changes due to organic enrichments in vineyard systems. Biol. Fertil. Soils 1998, 27, 417-424. [CrossRef]

26. Andersen, L.; Kühn, B.F.; Bertelsen, M.; Bruus, M.; Larsen, S.E.; Strandberg, M. Alternatives to herbicides in an apple orchard, effects on yield, earthworms and plant diversity. Agric. Ecosyst. Environ. 2013, 172, 1-5. [CrossRef]

27. Devetter, L.W.; Dilley, C.A.; Nonnecke, G.R. Mulches Reduce Weeds, Maintain Yield, and Promote Soil Quality in a ContinentalClimate Vineyard. Am. J. Enol. Vitic. 2014, 66, 54-64. [CrossRef]

28. Paoletti, M.G. The role of earthworms for assessment of sustainability and as bioindicators. Agric. Ecosyst. Environ. 1999, 74, 137-155. [CrossRef]

29. Edwards, C.A.; Bohlen, P.J. Biology and Ecology of Earthworms, 3rd ed.; Chapman \& Hall: London, UK, 1996; 426p.

30. Al-Shammary, A.A.G.; Kouzani, A.; Gyasi-Agyei, Y.; Gates, W.; Rodrigo-Comino, J. Effects of solarisation on soil thermal-physical properties under different soil treatments: A review. Geoderma 2020, 363, 114137. [CrossRef]

31. Anikwe, M.; Mbah, C.; Ezeaku, P.; Onyia, V. Tillage and plastic mulch effects on soil properties and growth and yield of cocoyam (Colocasia esculenta) on an ultisol in southeastern Nigeria. Soil Tillage Res. 2007, 93, 264-272. [CrossRef]

32. Kader, M.; Senge, M.; Mojid, M.; Ito, K. Recent advances in mulching materials and methods for modifying soil environment. Soil Tillage Res. 2017, 168, 155-166. [CrossRef]

33. Ernst, G.; Emmerling, C. Impact of five different tillage systems on soil organic carbon content and the density, biomass, and community composition of earthworms after a ten year period. Eur. J. Soil Biol. 2009, 45, 247-251. [CrossRef]

34. Correia, F.V.; Moreira, J.C. Effects of Glyphosate and 2,4-D on Earthworms (Eisenia foetida) in Laboratory Tests. Bull. Environ. Contam. Toxicol. 2010, 85, 264-268. [CrossRef]

35. Chan, K. An overview of some tillage impacts on earthworm population abundance and diversity-Implications for functioning in soils. Soil Tillage Res. 2001, 57, 179-191. [CrossRef]

36. Paoletti, M.; Sommaggio, D.; Favretto, M.; Petruzzelli, G.; Pezzarossa, B.; Barbafieri, M. Earthworms as useful bioindicators of agroecosystem sustainability in orchards and vineyards with different inputs. Appl. Soil Ecol. 1998, 10, 137-150. [CrossRef] 
37. Głąb, T. Impact of soil compaction on root development and yield of meadow-grass. Int. Agrophys. 2013, 27, 7-13. [CrossRef]

38. Moradi, J.; John, K.; Vicentini, F.; Veselá, H.; Vicena, J.; Ardestani, M.M.; Frouz, J. Vertical distribution of soil fauna and microbial community under two contrasting post mining chronosequences: Sites reclaimed by alder plantation and unreclaimed regrowth. Glob. Ecol. Conserv. 2020, 23, e01165. [CrossRef]

39. Jimenez, J.J.; Decaens, T. Vertical distribution of earthworms in grassland soils of the Colombian Llanos. Biol. Fertil. Soils 2000, 32, 463-473. [CrossRef]

40. Viljoen, S.; Reinecke, A. The temperature requirements of the epigeic earthworm species Eudrilus eugeniae (oligochaeta)—A laboratory study. Soil Biol. Biochem. 1992, 24, 1345-1350. [CrossRef]

41. Singh, J.; Schädler, M.; Demetrio, W.; Brown, G.G.; Eisenhauer, N. Climate change effects on earthworms-a review. Soil Org. 2019, 91, 114-138. [CrossRef]

42. Fründ, H.-C.; Egbert, E.; Dumbeck, G. Spatial distribution of earthworms [Lumbricidae] in recultivated soils of the Rhenish lignite-mining area, Germany. J. Plant Nutr. Soil Sci. 2004, 167, 494-502. [CrossRef]

43. Wever, L.A.; Lysyk, T.J.; Clapperton, M. The influence of soil moisture and temperature on the survival, aestivation, growth and development of juvenile Aporrectodea tuberculata (Eisen) (Lumbricidae). Pedobiologia 2001, 45, 121-133. [CrossRef]

44. Berry, E.; Jordan, D. Temperature and soil moisture content effects on the growth of Lumbricus terrestris (Oligochaeta: Lumbricidae) under laboratory conditions. Soil Biol. Biochem. 2001, 33, 133-136. [CrossRef]

45. Eriksen-Hamel, N.S.; Whalen, J.K. Growth rates of Aporrectodea caliginosa (Oligochaetae: Lumbricidae) as influenced by soil temperature and moisture in disturbed and undisturbed soil columns. Pedobiologia 2006, 50, 207-215. [CrossRef] 